\title{
Higher education in Indonesia: Contemporary challenges in governance, access, and
}

\author{
quality
}

\section{Chiara Logli}

This chapter presents the development of Indonesian higher education since its origins to current challenges in the fields of governance, autonomy, access, equity, quality, and internationalization. Indonesia has a massive and diversified tertiary education, including experiments in community colleges and online programs. The higher educational system remains mainly centralized, with the exception of some reforms towards financial autonomy. Insufficient public funding hinders the capacity to provide adequate teaching, research, and facilities among other aspects. The consequential rise in student fees contributes to an overrepresentation of students from Java, urban centers, and higher social classes.

\section{Key words}

Indonesia, higher education, equity, autonomy, internationalization, quality

\section{Introduction}

The largest archipelago in the world has a challenging higher education environment. Indonesian policy makers and educators confront the difficult task of meeting the needs of an enormous country with over 375 ethnicities, 700 languages, six officially recognized creeds (i.e., Islam, Protestantism, Catholicism, Hinduism, Buddhism, and Confucianism), the greatest number of Muslim adherents and the fourth highest population on the planet (i.e., 237 million people) scattered across 6,000 inhabited islands (Ananta 2013, Indonesian Central Agency on Statistics 2010).

Tensions arise as Islam accounts for 87 percent of Indonesians and the Javanese ethnicity — which is almost entirely Muslim — constitutes 40 percent of the inhabitants, while wielding the majority of political power. Indonesia has the $16^{\text {th }}$ largest economy in the world and the largest economy in the Association of Southeast Asian Nations (ASEAN), but inequality is rampant with 43.3 percent of the population living on less than US\$ 2 per day in 2012 (OECD/Asian Development Bank 2015). 
Indonesia also has the fourth largest education system in the world, behind China, India, and the U.S. (OECD/Asian Development Bank 2015). Higher education institutions (HEIs) have made remarkable advancements in their relatively young lives (Buchori and Malik 2004, Cummings and Kasenda 1989, Nizam 2006). However, they remain relatively peripheral (Welch 2012). For instance, no Indonesian university is highly placed among the rankings of world universities (OECD/Asian Development Bank 2015).

Issues of availability, affordability, equality, quality and relevance of education are a concern of the Ministry of Education and Culture (MoEC) as well as international organizations, such as the Asian Development Bank and the Organization for Economic Co-operation and Development (OECD). The 1996-2005 third plan by the Directorate General of Higher Education (DGHE) launched a "new paradigm" based upon five pillars of reform—autonomy, quality, accountability, accreditation, and evaluation (Koning and Maassen 2012). The DGHE long-term strategy of 2003-2010 highlighted again autonomy and quality along with access and equity. The 12/2012 Higher Education Act also covers key elements such as institutional autonomy, equitable access, quality assurance system, as well as strengthening of vocational education and training (Moeliodihardjo 2014).

This chapter presents the development of Indonesian higher education since its origins, through Dutch colonization and post-colonialism, to its contemporary features. The focus is on the macro level, with closer attention to the controversial issues of governance, autonomy, access, equity, quality, and internationalization.

\section{Origins of Indonesian higher education}

International ties permeate the history of Indonesian higher education from its beginning (Buchori and Malik 2004). Around the second century, Hinduism and Buddhism reached the 
island of Java; by the seventh century, monasteries offered monks access to basic literacy and religious knowledge. In the thirteenth century, Islam arrived and advanced teaching for notable men started in the pesantren (Islamic boarding school). Graduates either created their own pesantren or pursued additional training in the Middle East, such as at al-Azhar University in Cairo. Returning alumni often became ulama (Muslim scholar) who produced internationally renowned works.

In the colonial era (1500s-1942), the Dutch established the first formal and official universities in Java starting at the end of the eighteenth century. The medical school and law school in Jakarta, the engineering institute in Bandung, and the agriculture center in Bogor were founded to compensate for the shortage of Dutch experts, especially during World War One. Dutch was the exclusive language of instruction and served as an effective means of selection of male nobles across the thin numbers of high school graduates.

The student bodies reflected the colonial hierarchy, with the Dutch at the top and the indigenous people at the bottom. In 1930, 106 university students were children of Indonesian parents (Buchori and Malik 2004); in 1938, their number rose to 200 out of the total 1,000 students (Cummings and Kasenda 1989). Colonial universities were arenas of "social and cultural conflict" (Alisjahbana 1966, 26). On one hand, indigenous people increasingly attached more value to education, because it appeared as the only opportunity to climb the colonial hierarchy towards a higher social status and better jobs in their local communities. On the other hand, they feared that Dutch education could manipulate the youth, with consequential loss of their traditions.

\section{Post-colonial higher education}


With independence, secular and religious universities were formally established (Nizam 2006).

The first official Islamic university, Universitas Islam Indonesia, opened in 1945. The first Indonesian secular university with no colonial legacy, Universitas Gadjah Mada, was founded in 1949 (Buchori and Malik 2004). The 1961 Law Number 22 on Higher Education prescribed the establishment of at least one public university in each province of Indonesia to expand inclusive higher education (Mason, Arnove, and Sutton 2001).

Indeed, 23 new universities, institutes, and teacher training colleges were opened during that time (Koning and Maassen 2012). In 1978, there were 44 state universities and 324 higher education institutions (Rais 1987). Students in tertiary education increased from 6,000 in 1950 to 184,000 in 1965 (Pardoen 1998), 385,000 students in 1978, and 805,200 in 1983 (Rais 1987). The sharp increase is a reflection of the population explosion which took place in Indonesia from the 1950s. It was also allowed by the large oil revenues that became available in the 1970s and 1980s (Koning and Maassen 2012).

Since independence, the Indonesian educational system has aimed to advance knowledge as well as character and religiosity in order to benefit the country as a whole (Soedijarto 2009). Article 31 of the 1945 Constitution explains that the role of the government vis-à-vis education is to "increase the level of spiritual belief, devoutness, and moral character" and to "advance science and technology with the highest respect for religious values and national unity." The Higher Education Law of 1961 is still in effect today and states that the purpose of education is to build a society that embodies the five principles of the Pancasila (i.e., belief in one God, internationalism or humanitarianism, national unity, democracy based on deliberation as well as consensus, and social justice). Over the decades, the stress on national commitment translated in several variations of civic, religious, and service-based education (Logli 2015). 


\section{Current higher education system}

In Indonesia, tertiary education has a diversified structure. HEIs can be public or private, secular or religious, and of types of academic specialization—academy, polytechnic, college, institute, and university (Moeliodihardjo 2014, Altbach and Umakoshi 2004). The first two types of specialization are vocational, whereas the last three are academic. Vocational programs (D1-D4) lead to diplomas after one to four years of study, whereas a bachelor's degree (S1) lasts four years, with a further two years for a master's degree (S2) and additional three years for a $\mathrm{PhD}$ (S3) (OECD/Asian Development Bank 2015). As indicated by Table 1, the number of private colleges is striking, because the rising demand for higher education cannot be filled by the public sector (Welch 2012).

Table 1. Number of Indonesian HEIs (Year 2012-2013)

\begin{tabular}{|l|r|r|r|r|r|r|}
\hline & University & Institute & \multicolumn{1}{|c|}{ College } & Polytechnic & Academy & TOTAL \\
\hline Public & $52 *$ & 7 & 1 & - & 36 & 96 \\
\hline Private & 424 & 51 & 1,383 & 1,099 & 136 & 3,093 \\
\hline Islamic ** & 99 & 44 & 502 & & & 645 \\
\hline TOTAL & 575 & 102 & 1,886 & 1,099 & 172 & 3,834 \\
\hline
\end{tabular}

Note: * The public sector includes one Open University; ** data refer to 2011-2012.

Source: OECD/Asian Development Bank 2015, 187.

Two interesting recent developments regard the expansion of community colleges (Akademi Komunitas) and distance learning. In 2011, the Long-Term Development Plan for Higher Education requested the founding of community colleges in each district/city level by 2015 (OECD/Asian Development Bank 2015). In 2012, the latest Higher Education Act confirmed the importance of graduates' qualifications, including through the introduction of 
community colleges in all districts (Global Business Guide Indonesia 2013). In 2012-2013, 35 community colleges were developed throughout Indonesia (OECD/Asian Development Bank 2015). The government aims to establish 500 community colleges within the next few years (Clark 2014).

Community colleges provide 1-2 year vocational programs beyond high school (Moeliodihardjo 2014), mainly in the areas of manufacturing, nursing, automotive technology, and other trades (Clark 2014). They are established upon permission by the ministry to ensure that they have a sufficient basis in terms of quality and finance (OECD/Asian Development Bank 2015). To ensure quality, they are supported by stronger institutions during their establishment phase. For instance, the Bogor Agricultural University has assisted the launching of four community colleges on different islands.

There is also a growing interest in distance education in both government and private sectors (Soekartawi, Haryono, and Librero 2012). According to Jacob, "In Indonesia, increased access to higher education for previously underrepresented students cannot be achieved without mastering several forms of distance education" $(2012,228)$. The target groups of distance education are those who cannot attend regular schooling due to remote location, work schedule, or personal constraints. However, the promotion of higher education as vocational training is linked to political and market-driven rationales, especially in regards to standardization, efficiency, and technocracy of higher education (Mason, Arnove, and Sutton 2001). As a result, HEIs focus on relatively narrow, utilitarian aims rather than a more universal pursuit of knowledge.

Similar to the rest of Southeast Asia, in Indonesia distance education started in the field of teacher training, which is viewed as particularly impactful for national development 
(Soekartawi, Haryono, and Librero 2012). Currently, five government institutions are responsible for the development and implementation of distance education. The National Center for Teacher Training and Development by Correspondence (PPPG) and the National Center for Technology and Communication for Education (PUSTEKKOM) were founded in 1950 and 1974 respectively to provide distance education programs for teachers. The Indonesian Distance Learning Network (IDLN) and the Southeast Asian Ministries of Education Organization Regional Open Learning Center (SEAMOLEC) were initiated in 1993 and 1995 respectively to support research, development, training, and sharing of resources in the field of distance education.

The fifth online institution, the Open University (Universitas Terbuka or UT), was founded in 1984 to absorb the bulk of senior high school graduates in remote areas. Yet, currently most of the students are working people who cannot leave their jobs to attend face-toface classes. UT enrolls about 350,000 students and is one of the top 10 mega-universities in the world (i.e., having more than 100,000 students). It provides 700 courses in 44 departments across five collages—mathematics, natural sciences, economics, education, and social sciences.

In the past, the government authorized the UT to be the only university to offer distance education programs in Indonesia. Presently, other HEIs are allowed to offer such programs. As telecommunication infrastructures and university internationalization increase, the demand for distance education programs is expected to expand. To overcome students' isolation, most education institutions provide student support services, such as administrative consultation, academic tutorials, and interactive teleconferencing. Course materials are still largely print-based as information and communication technologies remain limited.

Quality internet connections are not always available in even the best universities, let alone in remote HEIs (Jacob et al. 2012). Technology limitations also impact the access to 
electronic academic journals, virtual teaching platforms, and training for instructors and students on how to use available online tools. Other challenges in distance education refer to qualified personnel, effective coordination among educational institutions offering distance education programs, and the prevailing perception that conventional schooling is superior to distance education.

In general, distance education experiences in the ASEAN region indicate relatively successful endeavors. Although research on the quality of distance education in ASEAN is still limited, the few existing studies show that alumni of open and conventional universities perform equally in the workforce as well as in the entrance exam to graduate schools in Indonesia and overseas.

\section{Tensions around governance and autonomy}

In recent decades, shifts in management and accountability have generated problematic and controversial results in Indonesia. Under the MoEC, the DGHE is responsible for general tertiary education (public and private), whereas the Ministry of Religious Affairs (MoRA) oversees Islamic institutions (public and private) (OECD/Asian Development Bank 2015). Islamic institutions under MoRA are public Islamic universities (UIN) and public Islamic institutes (IAIN) (Moeliodihardjo 2014, Asari 2007).

Private HEIs are managed by either a foundation or a corporation (Welch 2012). In 1998, the government stopped issuing permits for the founding of private universities, due to issues of quality control as addressed below (NUFFIC 2015). Currently, private universities are established under strict conditions. The government has also encouraged smaller colleges to merge in order to create larger and better-quality institutions, but with limited success due to conflicting interests and the absence of parliament support (Moeliodihardjo 2014). 
Additionally, various ministries supervise the institutes that supply them with technical human resources. For instance, the Military Academy is under the Ministry of Defense and the Institute of Accountants is under the Ministry of Finance (MoF). In most cases, students in these "service institutions" receive full fellowships and have to work as civil servants at the respective ministry for a few years after graduation.

Since the 1990s, the DGHE has supported university autonomy, as a result of external pressures by international agencies (Welch 2012). In 1999, a first legislative act in support of autonomy (Government Regulation No. 61/1999) stipulated that certain public universities were “State Owned Legal Entity Universities” (Perguruan Tinggi Badan Hukum Milik Negara, PTBHMN or in short BH) with greater self-governance and financial independence than regular "public entities" (Jacob et al. 2012, Sunarto 2015, Moeliodihardjo 2014, Kusumadewi and Cahyadi 2013).

In 2000, the top public universities - University of Indonesia, Institute of Agriculture Bogor, Institute of Technology Bandung, and Gadjah Mada University—were selected to function as "Legal Entity guides" (Beerkens 2002). Later, the Legal Entity status was awarded to an additional three colleges-University of North Sumatera, Indonesia Educational University, and Airlangga University — and four other institutions are in the pipeline to be converted to autonomous universities - Padjadjaran University, Diponegoro University, Nopember Institute of Technology, and Hasanuddin University (Moeliodihardjo 2014). All BH universities are located in Java, except the University of North Sumatera and Hasanuddin University.

BH universities have a dual management system (OECD/Asian Development Bank 2015). On one hand, a university senate consists of campus faculty members and is the highest authority in academic matters. Compared to other HEIs, BH universities have a greater freedom 
to formulate their own missions and development strategies. For instance, they can open and close study programs without having approval from the ministry.

On the other hand, $\mathrm{BH}$ universities have boards of trustees (Majelis Wali Amanat, MWA), which consist of both internal and external members (a majority in some of the institutions), namely representatives from MoEC, the university senate, staff/student body, and society (Beerkens 2002). The board oversees the general operation, budgetary control, and appointment of the rector (Moeliodihardjo 2014). The rector selects the deans, after considering nominations from the respective departmental senates. Financially, BH universities receive block grants, reallocate money between budget lines, use their self-generated income, and accumulate reserves (OECD/Asian Development Bank 2015).

The DGHE has also created "Public Service Agencies" (Badan Layanan Umum or BLU) with an intermediate degree of autonomy between the $\mathrm{BH}$ and all the other HEIs (OECD/Asian Development Bank 2015, Kusumadewi and Cahyadi 2013). The autonomy of BLU institutions is limited to managing financial matters; they do not have trustees and the rector is appointed by, and reports to, MoEC after considering nominations from the respective university senate (OECD/Asian Development Bank 2015). This new status has been given to 21 institutions of a certain strength and size.

Criticisms target the dearth of BH self-governance. The ministry is represented in the boards of trustees (Beerkens 2002). Public universities have to comply with the regulations for all governmental offices, including on financial management under the MoF and on personnel management under the National Civil Service Agency (BKN) (Moeliodihardjo 2014). All institutions develop their own curriculum with reference to National Higher Education Standards (OECD/Asian Development Bank 2015). In addition, national regulations have not been adapted 
to $\mathrm{BH}$ guidelines and input from the government is still necessary on numerous matters

(Beerkens 2002). The provincial policy continues to be centralistic, while autonomy regulations lack clarity and generate confusion for all parts involved (Sunarto, Heng, and Saifuddin 2004).

Critics also condemn the push towards financial autonomy and privatization (Sunarto 2015, Jacob et al. 2012, Beerkens 2002, Kusumadewi and Cahyadi 2013). They find that the regulations harm low-income students, governmental responsibility to education, unbiased research findings, academic excellence and collegiality (Susanti 2011). Over the years, the Indonesian Supreme Court has been requested to review the 2003 law, 2008 law, and 2012 Higher Education Act in order to stop the corporatization of higher education (Moeliodihardjo et al. 2012, Sunarto 2015, Jacob et al. 2012). As a result, the Indonesian Supreme Court revised a number of articles in the 2003 law, struck-down the entire 2008 law as unconstitutional, but maintained the 2012 Higher Education Act in favor of private funding for public universities (Sunarto 2015, Jacob et al. 2012, Kusumadewi and Cahyadi 2013).

Empirical studies found that professors, administrators, and students as well as the public at large are concerned about limited governmental funding, increasing tuitions, commercialization, and the problems that they cause in regard to quality, equity, and intellectual freedom in education (Logli in press-b, 2015, Jacob et al. 2012).

\section{Ongoing financing challenges}

Indonesia is one of few countries with a constitution that obliges the government to assign at least 20 percent of the national budget to education, as per amendment to Article 31 in the 2000s. However, this promise has not been fulfilled. For instance, in 2000-2001 Indonesia allocated 10 percent of its governmental budget to education, compared to 18 percent in Myanmar or 30 percent in Thailand (Soedijarto 2009). 
Within higher education, the funding structure includes government, student fees, philanthropies, and private enterprises (Moeliodihardjo 2014). In 2011 total expenditure was about 1.2 percent of GDP, which is low compared with Malaysia (1.69 percent), but higher than the figures for Vietnam (1.18 percent) and Thailand ( 0.71 percent) (OECD/Asian Development Bank 2015). The DGHE budget has increased from Indonesian Rupiah (IDR) 14,058 trillion in 2009 (Moeliodihardjo 2014) to IDR 39,896 trillion in 2014 (OECD/Asian Development Bank 2015). Since 2012, a new DHGE formula allocates monies based on enrollment, field of study, geographical location, and special affirmative action policy (Moeliodihardjo 2014). The budget cycle begins with the solicitation of proposals from public universities as early as June and concludes with parliamentary decision by December.

Private HEIs receive 8-10 percent of the DGHE budget, while the remainder goes to the public HEIs (OECD/Asian Development Bank 2015). Private HEIs are mainly supported by student fees, but are also eligible for subsidies, such as in partial salary support for instructors, laboratory equipment, and competitive grants (Moeliodihardjo 2014). For instance, approximately 10 percent of academic staff at private HEIs are paid by government (Welch 2012). The government also provides scholarships for staff to pursue advanced degree and extends civil servants status to some instructors (Moeliodihardjo 2014).

At public institutions, fee levels for undergraduate programs are centrally fixed, apart from the top-tier autonomous universities, which, like the private institutions, set their own fees (OECD/Asian Development Bank 2015). In addition, self-generated revenues, including reserves, are considered state revenues - they must be deposited to the State Treasury and can only be used after acquiring MoF approval (Moeliodihardjo 2014). The BH and BLU universities are exempted from these provisions and have a certain level of autonomy in managing their 
revenue. The DGHE support for public institutions is still insufficient compared to their needs (Hawkins 2011). In some large public universities, the share of government allocation in support of the overall budget is less than 20 percent (Moeliodihardjo 2014).

As a result of low governmental funding, the proportion of revenue acquired from students has steadily increased over the last 10 years. An average Indonesian household would have to spend one-third of its annual expenditure to fund a family member participating in higher education (OECD/Asian Development Bank 2015). For example, in the 2004-2005 academic year, the total cost carried by students ranged from IDR 6.8 million for the lower public HEIs to IDR 20.8 million for the higher public HEIs, while it was about IDR 31 million for private HEIs (Wicaksono and Friawan). In addition, institutions have established Special Passage (Jalur Khusus) into admissions for students who can pay higher fees regardless of their entrance examination results (Welch 2012). For instance, in 2004, after privatization, the Institute of Technology Bandung (ITB) received 29 percent of its annual operational cost from the government, 41.5 percent from research projects and 8.3 percent from student tuition fees. To cover the remaining 21 percent of its financial needs, ITB offered the Special Passage to 20 percent of its applicants who could not pass the national entrance exam but would pay the higher entrance fee to the university for a minimum of IDR 45 million (approximately US\$4,500) (Susanti 2011, Welch 2007). At ITB’s Physical Engineering Department, ten places were offered at the cost of IDR 225 million (around US\$22,500) each.

The rise in students' fees triggered public outcry (Moeliodihardjo 2014). Thus, parliament Law 12/2012 and MoEC decree 55/2013 limit the proportion of the budget acquired from students not to exceed 30 percent in any public university, although flexibility is given to postgraduate and non-regular programs. In 2010, the Constitutional Court declared 
unconstitutional the 2008 law in support of the charging of differential fees, yet the practice remains (Welch 2012, Logli 2015). Corruption is widespread in Indonesian society, including in higher education (Welch 2012). In 2012, the Supreme Auditing Board found AU\$ 161.5 million in accounting irregularities in the Ministry of Education's financial reporting of 2011 out of AU\$ 27 billion budget (Kubo 2013).

Since 2012, the DGHE has expanded its scholarship support, which includes various schemes: (a) Bidik Misi for poor students with a good academic record; (b) BBM and PPA for students with strong academic or non-academic achievement as well as students from lowincome families; (c) OSI for students who win the International Science Olympics competition (Moeliodihardjo 2014, OECD/Asian Development Bank 2015). In 2012, the government target was that at least 20 percent of students should receive scholarships or financial assistance, but only 10 percent were reached. In addition, private scholarships have also been established by companies and foundations (OECD/Asian Development Bank 2015).

\section{Predicaments of access and equity}

The massification of Indonesian higher education has produced a system that is large and diversified, but unequal with an overrepresentation of students from Java, urban centers, and higher social classes. Indonesian enrollment amounted to a mere 106 students in 1930, but reached over 108,000 by 1961, 4.2 million in 2008, and 5.9 million in 2012 (Buchori and Malik 2004, UNESCO 2010, OECD/Asian Development Bank 2015). In 2012, the tertiary education enrollment rate was 31.5 percent of the relevant age cohort, compared to 21.3 percent in 2008 (OECD/Asian Development Bank 2015). This percentage is above the percentages of countries like Laos, Vietnam and the Philippines, but below that of Malaysia (36 percent) and Thailand 
(51.2 percent). In 2011, 8.8 percent of the population completed higher education, compared to 3.6 percent in 2000 (OECD/Asian Development Bank 2015).

Of the national enrollment, approximately 25 percent are in public institutes (OECD/Asian Development Bank 2015), 60 percent in the private sector (Moeliodihardjo 2014), and 15 percent in Islamic higher education (Buchori and Malik 2004). As shown in Table 2, enrollment in the private sector expands consistently faster than in other counterparts and helps to provide higher education outside Java (Moeliodihardjo 2014).

Table 2. Total enrolment in higher education

\begin{tabular}{|l|r|r|}
\hline & Year 2009/2010 & \multicolumn{1}{|c|}{ Year 2012/2013 } \\
\hline Public* & $1,636,122$ & $1,649,267$ \\
\hline Private & $2,451,451$ & $3,645,869$ \\
\hline MORA & 503,439 & 653,846 \\
\hline State** & 66,535 & 103,072 \\
\hline TOTAL & $4,657,547$ & $6,052,054$ \\
\hline
\end{tabular}

Notes: * Includes Open University; ** HEIs operated by ministries other than MOEC/MORA.

Source: OECD/Asian Development Bank 2015, 188.

The distribution of students according to their fields of study show 16 percent in technology, 10 percent in science and natural sciences, and 74 percent in social sciences and education (Sitepu 2013). Private institutions open more opportunities to the fields of social sciences and education, because their operational costs are considered low compared to those of natural sciences and technology (Sitepu 2013).

Competition for entrance into public universities is fierce (Clark 2014). The national examination has changed over the years, but is still used to apply for university (Rachman 2015, 
OECD/Asian Development Bank 2015). It is often criticized for being associated with passive learning, excessive public cost, and corruption (2012, April 17, Sihombing, Mattangkilang, and Setuningsih 2013, April 22). Every year, more than 450,000 high school graduates take the national public university entrance examination to compete for 75,000 seats, less than 17 percent (Nizam 2006). Those less fortunate who fail the entrance examinations will go to alternative private institutions (Sitepu 2013).

Indonesia has developed an expanded but socially and geographically skewed array of tertiary education institutions. Only 3.3 percent of higher education students stem from the lowest 20 percent of income groups, whereas 30.9 percent are from the highest quintile (Asian Development Bank 2012, Nizam 2006). Because public institutions have a better reputation than private universities, students from wealthier families tend to gravitate to state colleges, while students with modest background often end up in private HEIs after failing to gain access to public ones (Buchori and Malik 2004, Susanti 2011).

As confirmed by Table 3, the distribution of institutions is highly skewed toward Java and Sumatra, compared to Maluku and Papua (Moeliodihardjo 2014). In particular, the island of Java counts for 6 percent of the land, but 60 percent of the population, 75 percent of the college students, and all of the prestigious universities (Hartano 2009, Buchori and Malik 2004).

Table 3. Distribution of HEIs across the archipelagos (Year 2012-2013)

\begin{tabular}{|l|r|r|r|r|r|}
\hline & \multicolumn{2}{|c|}{ Public } & \multicolumn{2}{c|}{ Private } & \\
\hline & Polytechnics & $\begin{array}{r}\text { Other } \\
\text { HEIs }\end{array}$ & Polytechnics & $\begin{array}{l}\text { Other } \\
\text { HEIs }\end{array}$ & TOTAL \\
\hline Java & 12 & 24 & 76 & 1,438 & 1,550 \\
\hline Sumatra & 9 & 14 & 32 & 784 & 839 \\
\hline
\end{tabular}




\begin{tabular}{|l|r|r|r|r|r|}
\hline Sulawesi, North Maluku & 4 & 8 & 8 & 364 & 384 \\
\hline Kalimantan & 5 & 5 & 11 & 156 & 177 \\
\hline $\begin{array}{l}\text { Bali, West/East Nusa } \\
\text { Tenggara }\end{array}$ & 3 & 5 & 5 & 135 & 148 \\
\hline Maluku, Papua & 3 & 4 & 4 & 80 & 91 \\
\hline TOTAL & 36 & 60 & 136 & 2,957 & 3,189 \\
\hline
\end{tabular}

Source: OECD/Asian Development Bank 2015, 190.

In addition, students from urban areas exceed students from rural areas in high numbers (Akita and Miyata 2008). As shown in Table 4, some 10 percent of the urban population has a university degree whereas only 3 percent of rural people do (OECD/Asian Development Bank 2015). The level of educational attainment appears to correlate with poverty levels and the availability of services across Indonesia.

Table 4. Educational attainment in HEIs—urban/rural classification (Year 2011)

\begin{tabular}{|l|r|r|}
\hline \multirow{4}{*}{ Urban } & Male & 10.65 \\
\cline { 2 - 4 } & Female & 10.2 \\
\cline { 2 - 4 } Rural & Male + Female & 10.42 \\
& Female & 2.89 \\
\cline { 2 - 4 } & & 3.04 \\
\cline { 2 - 4 } & Male + Female & 2.97 \\
\hline \multirow{3}{*}{ Urban + Rural } & Male & 6.79 \\
\cline { 2 - 4 } & & 6.67 \\
\cline { 2 - 4 } & Male + Female & 6.73 \\
\hline
\end{tabular}

Source: OECD/Asian Development Bank 2015, 62. 
Female and male numbers in public education are equal (OECD/Asian Development Bank 2015). Yet, there are differences between the general and faith-based institutions; for instance at the Islamic institutions only 17 percent of PhD students are female. A new challenge is to influence the stereotyped choices of subjects, so that more female students opt for highpriority fields such as science, technology and engineering rather than their traditional disciplines like health and education.

My empirical findings confirmed the overrepresentation of students from Java, urban centers, and higher social classes (Logli 2015, in press-b). In fact, most families cannot afford tuition and relocation. In addition, the national examination determines university access based on scholastic merit, yet the quality of $\mathrm{K}-12$ education is greater in Java than in other islands, so pupils not from Java do not have an equal chance to succeed in the national exam. The growing homogeneity among students also increases homogeneity among faculty and executives, who are predominantly alumni.

Accessible education, in terms of proximity and cost, is essential to guarantee equal access (Buchori and Malik 2004). To expand academic opportunities, the government has undertaken various initiatives. First, the 2012 Higher Education Act allows HEIs to rely on different student entrance systems (Sunarto 2015). All public universities, including BH ones, have to take 50 percent of students from the National Admissions scheme and at least 20 percent of students from socio-economically disadvantaged groups (OECD/Asian Development Bank 2015). The law formalizes the efforts of universities like Universitas Gadjah Mada that have been utilizing for decades a variety of instruments for admissions to prioritize both merit and differentiated backgrounds (Logli 2015, in press-b). Second, new public institutions are mostly established in underserved areas, such as in Merauke (Papua), Morotai island (Sulawesi), and 
Tarakan island (Kalimantan) (Moeliodihardjo 2014). Third, the government has diversified higher education, including community colleges outside Java and distance learning, as elaborated above. Fourth, the DGHE has added a new scholarship scheme (Bidik Misi) as also mentioned before.

\section{Quality: Teaching and research}

The rapid growth of the tertiary education system outpaced the capacity to provide adequate teaching, research, and facilities among other aspects (Tadjudin 2009, Welch 2007, 2011, OECD/Asian Development Bank 2015, Altbach and Umakoshi 2004, Mason, Arnove, and Sutton 2001). Qualified faculty, technology-based research, and scientific equipment demand a budget and organization that is rarely available in the existing public universities and virtually unthinkable in the underfunded private institutions (Buchori and Malik 2004, Nizam 2006, Soedijarto 2009). More than 70 percent of a typical HEI budget is absorbed by personnel costs, leaving all other education needs underfund and underserved (Moeliodihardjo 2014).

In public universities, all teaching and administrative staff are civil servants - they comply with the Law on Civil Service and are centrally managed by the National Civil Service Agency (BKN) (Moeliodihardjo 2014). Under this Law only the BKN has the authority to recruit, promote, and terminate personnel. Mobility requires a long bureaucratic procedure and employees have to climb up the ladder from the lowest rank, regardless of their background. Recognizing this problem, in 2012 the parliament passed a new law on Civil Apparatus allowing rectors to exercise their authority, including through horizontal recruitment across institutions. However, at the micro level, academic departments continue to routinely hire their own graduates and assign promotions based on seniority rather than performance (Pincus 2015, Logli 2015). 
In Indonesia, instructors are often underqualified (Jacob et al. 2012). The 2005 Law requires all university teachers to hold at least a Master's degree (Moeliodihardjo 2014). As shown in Table 5, 27.50 percent of lecturers still had only a bachelor degree in 2012 (OECD/Asian Development Bank 2015).

Table 5. Qualification of teaching staff in HEIs (Year 2014)

\begin{tabular}{|l|l|l|l|l|l|l|}
\hline & \multicolumn{2}{|c|}{ Bachelor } & \multicolumn{2}{c|}{ Master } & \multicolumn{2}{c|}{ Doctorate } \\
\hline $\mathbf{2 0 0 9}$ & 69,770 & $43.70 \%$ & 76,455 & $47.89 \%$ & 13,435 & $8.41 \%$ \\
\hline $\mathbf{2 0 1 2}$ & 48,125 & $27.50 \%$ & 106,225 & $60.70 \%$ & 20,650 & $11.80 \%$ \\
\hline
\end{tabular}

Source: Moeliodihardjo 2014, 9.

The geographical disparity is also quite striking. More than two-thirds of Ph.D. holders (S-3) — generally the best indicator of research capacity —are from institutions in Java (OECD/Asian Development Bank 2015). They usually teach at the few elite universities (Moeliodihardjo 2014). Polytechnics need teachers with rich industrial experience and the requirement for a Master's degree may sacrifice vocational expertise (OECD/Asian Development Bank 2015). Realizing this risk, the government is currently developing a system of converting industrial experiences into academic achievement.

During the period 2007-11, increasing enrollment and a falling number of lecturers has led to a relatively high student/lecturer ratio-31 at the public institutions and 28 in the private sector (OECD/Asian Development Bank 2015). In addition, academics are poorly remunerated and driven to seek complementary income off campus (Altbach and Umakoshi 2004, Welch 2012). They often devote more of their time to consulting work for government offices and corporate business than teaching and conducting research (Altbach and Umakoshi 2004). In public institutions, some faculty members hold permanent positions but also teach at private 
university. In the private sector, many instructors teach at multiple universities, which usually cannot afford full-time quality professors. As a result, students are deprived of the opportunity to sufficiently interact with their instructors outside of class and to receive the assistance that they need for their learning.

Table 6. Numbers of teachers in HEIs (Years 2007-2013)

\begin{tabular}{|l|l|l|l|l|l|l|l|}
\hline $\mathbf{2 0 0 7 / 0 8}$ & $\mathbf{2 0 0 8} / \mathbf{0 9}$ & $\mathbf{2 0 0 9 / 1 0}$ & $\mathbf{2 0 1 0} / \mathbf{1 1}$ & $\mathbf{2 0 1 1} / \mathbf{1 2}$ & $\mathbf{2 0 1 2} / \mathbf{1 3}$ & $\mathbf{2 0 1 3 / 1 4}$ & \% Change \\
\hline 250,357 & 228,781 & 233,390 & 207,507 & 192,944 & 192,944 & 209,830 & $-16 \%$ \\
\hline
\end{tabular}

Source: OECD/Asian Development Bank 2015

According to my empirical studies at the micro level, Indonesian students and faculty members generally call for more diversity in all aspects of teaching and learning. They are especially concerned about the over-representation of Javanese and Muslim perspectives across campus population, course content, and teaching strategies. Therefore, they advocate for (a) more students and professors from outside Java; (b) overt and hidden curricula that are more relevant, interdisciplinary, and free from issues of Javanization and Islamization; (c) alterations in religion and citizenship classes towards multicultural models; (d) expansion of the two-month community service (Kuliah Kerja Nyata, KKN); (e) inclusive and progressive pedagogies; (f) interventions on fundamentalist Islamic student groups that do not embody multicultural values (Logli 2015, in press-a, b).

The number of patents and international publications has increased in the last few years (Moeliodihardjo et al. 2012). In 2012, university researchers published 16,139 articles (ranked sixty-third in the world) and 126 patents were awarded to them. Most of the authors have earned their degree from overseas universities, and have successfully capitalized the experiences and their networks acquired during their study. 
However, these numbers reflect just 6.3 percent of lecturers and the figure for contributors to international journals is 0.68 percent (OECD/Asian Development Bank 2015). Only two to three private institutions are currently active in research (Moeliodihardjo 2014). Public Islamic institutes (IAIN) have started to establish some research centers and to promote publishing, especially in the campuses in Yogyakarta and Jakarta (Buchori and Malik 2004).

Compared to neighboring countries, the relatively low research outputs are correlated with the insufficient budgets allocated for research (Moeliodihardjo 2014). Government funding for research has more than tripled from 2006 to 2012 and the aim is to reach 1 percent of GDP by 2025 (OECD/Asian Development Bank 2015). In 2012, Indonesia only allocated 0.09 percent of its GDP for research, which is far behind Malaysia ( 0.7 percent), India ( 0.85 percent), or China (1.6 percent). Within higher education, the proportion allocated for the Directorate of Research and Community Services is around IDR 436 billion, 1.34 percent of the current DGHE budget; in comparison, one leading Indonesian pharmaceutical company, PT Kalbe Farma, spends IDR 200 billion annually for its research and development (Moeliodihardjo et al. 2012). There have been attempts by at least three governments — acts 25/2007, 35/2007, and 38/2008 - to introduce incentives and facilitate industries to invest in R\&D; yet none has been effective due to lack of detailed implementation planning.

By law, the function of the tertiary education institutions is described as tri dharma: teaching, research and community service. According to OEDC/Asian Development Bank, contributing to all three functions is unrealistic and undesirable due to the wide differences across institutional capacities and missions (2015). The majority of institutions do not have the financial and academic basis to conduct research; thus, they should concentrate their efforts on 
developing high-quality relevant teaching. The advantage of having a diversified system can only be exploited in full if institutions stick to their roles.

Quality assurance training is also needed at the administrator level, including in leadership, management, governance, academic writing, student affairs, as well as establishing international partnerships, internship programs, and industry advisory councils (Jacob et al. 2012).

\section{The limits of accreditation}

An accreditation system attempts to assess the progress and quality of Indonesian higher education. Law 12/2012 stresses the implementation of both internal and external systems to assess the quality of higher education (Moeliodihardjo 2014). Institutional evaluation was established in 2008 and is carried out by the higher education institutions themselves (OECD/Asian Development Bank 2015). It is conducted by independent consultants who evaluate the quality of staff, facilities, infrastructure, learning processes, governance and management, as well as the employability of its graduates among other factors (Moeliodihardjo 2014). Its effectiveness varies from institution to institution.

External accreditation has been compulsory for all public and private institutes since 1997 (OECD/Asian Development Bank 2015). It is carried out by the National Accreditation Board for Higher Education (Badan Akreditasi Nasional Perguruan Tinggi or BAN-PT) which falls under the MoEC (OECD/Asian Development Bank 2015). It is normally conducted every five years for each program or institution. Undergraduate institutions are classified into four levels from A (satisfactory) to D (unsatisfactory) (Jacob et al. 2012).

Table 7. Accreditation in HEIs 


\begin{tabular}{|l|l|l|l|l|l|l|}
\hline & \multicolumn{2}{|c|}{$\begin{array}{c}\text { Study programs in public } \\
\text { universities }\end{array}$} & \multicolumn{2}{c|}{$\begin{array}{c}\text { Study programs in private } \\
\text { universities }\end{array}$} & \multicolumn{2}{c|}{ Total } \\
\hline A & 1,274 & $22 \%$ & 427 & $3 \%$ & 1,701 & $9 \%$ \\
\hline B & 3,231 & $55 \%$ & 4,068 & $33 \%$ & 7,299 & $40 \%$ \\
\hline C & 1,335 & $23 \%$ & 7,996 & $64 \%$ & 9,331 & $51 \%$ \\
\hline
\end{tabular}

Source: OECD/Asian Development Bank 2015

The biggest challenge is that approximately 20 percent of institutions or study programs are unaccredited. The backlog reflects a lack of capacity in BAN-PT, due to a shortage of staff and the rapid expansion of the higher education sector. Current emergency measures give institutions temporary accreditation at "C" level (the pass level) without any accreditation process. Regulatory capacity is also not aided by geographical barriers, which pose problems in transportation, communication, and administration, including obtaining timely and accurate information about enrollments, staffing, and buildings (Welch 2012).

Accreditation show that the quality of public institutions is significantly higher compared to programs offered by private institutions (Moeliodihardjo 2014). The top 15 or 20 private institutions appear to have standards comparable with the better public institutions (OECD/Asian Development Bank 2015). Nevertheless, on the whole the contribution of the private sector to growth has been at the expense of quality and some private institutions can be regarded merely as "expansion absorbers." Private institutions are generally weaker in terms of size, staff qualifications, infrastructure, equipment and facilities. They can be extremely small, as few as 500 students. The Islamic institutions, both public and private, fall somewhere between the results of the general public and private institutions (OECD/Asian Development Bank 2015).

\section{Internationalization}


Indonesian campuses have become increasing international due to a variety of forces. Indonesia has been accepting assistance from Western agencies, including the Ford Foundation, the Rockefeller funds, USAID, and the World Bank (Moeliodihardjo 2014, Altbach and Umakoshi 2004, Mason, Arnove, and Sutton 2001). For instance, USAID sponsored initiatives that accelerated the number of Indonesian faculty members with advanced degrees from U.S. universities. American-educated faculty members were awarded leading positions in Indonesian institutions which led to changes in education based on aspects of the U.S. system. As a result, in the late 1970s the higher education system switched from Dutch influences to the American (Anglo Saxon) model, except in some areas such as medical and vocational education where some forms of the European model remained (Moeliodihardjo 2014). The Anglo-American model highlights standardized learning, autonomy, and internal efficiency.

After the 1997 Asian currency crisis, the IMF, World Bank, and Asian Development Bank increased their influence by providing a US\$ 23 billion bailout with the usual strings attached to structural adjustments (Welch 2012). Interventions in support of financial autonomy and privatization decreased real wages and increased poverty, with significant effects in higher education, both on the governmental capacity to provide subsidies to universities and on parents' capability to pay for their children's college. Despite imposing structural adjustment programs, international institutions carefully avoid financial responsibility and liability for consequences.

In 2010, U.S. President Barack Obama launched a five-year US\$ 165 million investment towards the expansion of higher education collaboration between the U.S. and Indonesia (Mengglobal 2013, March 28). The Comprehensive Partnership aims to enhance the quality, volume, and diversity of exchanges of students, faculty, and researchers (Geoffroy et al. 2009). In addition, it attempts to strengthen the capacity of educational institutions in each country, so 
that they can improve academic performance, mutual knowledge, and international standards. It engages government, university, foundation, NGO and private sector participants (Merrill 2012). For instance, it has expanded Fulbright and Peace Corps programs, scholarships for student and faculty, English/Indonesian language trainings, university-to-university partnerships, and USAID grants towards efficient management, scientific research, and community colleges in Indonesia.

The Indonesian government asserts the necessity of internationalization for universities, for instance through the 2003-2010 National Education Strategic Plan (Soejatminah 2009). Every university is expected to contribute to national competiveness as well as to counter possible negative effects of globalization. The practice of internationalization by Indonesian universities includes websites in English, information and communication technology, acknowledgement of internationalization (e.g., "to be world class University"), websites for international matters, and internationalization of the curriculum and student body.

The Higher Education Act of 2012 in Indonesia has catalyzed the internationalization of higher education (Global Business Guide Indonesia 2013). It allows foreign universities to set up branches and research centers, provided that they are accredited by their country of origin, are not for profit, collaborate with local universities, prioritize the employment of local Indonesian faculty members, and promote local civic and religious values. However, the Indonesian government holds jurisdiction over the disciplines in which foreign universities may operate although they will have control over setting their own curricula.

Some critics find the highly restrictive conditions of the law inadequate in today's globalized world (Pincus 2015). Others are concerned that foreign universities will poach the best lecturers and students from local institutions because they will have better resources (Pincus 2015). They also condemn the practice that international education tends to target students with 
especially strong English skills and an ability to afford international tuition rates (Jacob et al. 2012).

Indonesian university students make up about 1 percent of global internationally mobile students (Irandoust 2014). Annually 30,000 Indonesian higher education students study abroad, about 0.8 percent of the total, compared with 46,000 (6.1 percent) from Malaysia, 24,000 (0.9 percent) from Thailand, and 28,000 (1.9 percent) from Vietnam. The top five destinations for Indonesian students are Australia (10,500), U.S. (7,500), Malaysia (4,500), Germany $(1,700)$, and Japan (1,500). Australia is the number one choice for Indonesians abroad, mainly due to geographic proximity, perceived institutional quality, and English-medium instruction (Clark 2014).

The number of inbound international students is about 3,000 ( 0.1 percent $)$ students, compared to 24,400 (3.3 percent) from Malaysia, 11,000 (0.5 percent) from Thailand, and 3,200 (0.2 percent) from Vietnam (Irandoust 2014). The main countries of origin are Malaysia, East Timor, South Korea and Japan (Soejatminah 2009). The top five preferred study areas include medical, social sciences, engineering, Indonesian language, and pharmaceutical.

Indonesian universities, including Islamic institutions, cooperate with a variety of prominent universities overseas, such as in the U.S., Canada, Australia, and Europe (Buchori and Malik 2004). Indonesia is part of a pan-Islamic network of the Organization of the Islamic Conference (OIC) that aims to boost the quality of Islamic institutions, since only Istanbul University is listed among the Shanghai Jiaotong top 500 and in a relatively low position (Welch 2012). Part of a wider quality problem among universities in OIC member countries is that the entire Muslim world comprises one-fifth of humanity but has less than 1 percent of its scientists 
who generate less than 5 percent of its science and make barely 0.1 percent of the world's original research discoveries each year.

Depending on the institution, internationalization can infuse campus life, including international discourse in the curriculum and intercultural contact among students (Logli 2015, in press-b, a). According to my empirical studies, Indonesian students and faculty members generally call for further opportunities for campus internationalization, intercultural contact, and intellectual freedom.

\section{Conclusion}

This chapter has examined the current challenges in Indonesian higher education in the fields of governance, autonomy, access, equity, quality, and internationalization. With 43 percent of the Indonesian population being under 25 years old, tertiary education plays a key role in the future of the country (OECD/Asian Development Bank 2015). For instance, in 2013 the Boston Consulting Group reported that by 2020 Indonesian companies will struggle to fill half of their entry-level positions, due to low enrollment and standards in higher education (Clark 2014). Indonesian people generally regard university degrees as means of upgrading socioeconomic mobility (Oey-Gardiner and Suprapto 1996, Nizam 2006, Jacob et al. 2012). Yet, in addition to economic considerations, higher education is also responsible to develop global citizens who can contribute to both national and international landscapes in the twenty-first century. While this chapter mainly focused on government and university policies at the macro level, considering matters of curriculum, pedagogy, and campus life is also important in the improvement of higher education (Logli 2015, in press-a, b). 


\section{References}

Akita, T. and S. Miyata. 2008. "Urbanization, Educational Expansion, and Expenditure Inequality in Indonesia in 1996, 1999, and 2002." Journal of the Asia Pacific Economy, No. 3 (2):147-167.

Alisjahbana, S. 1966. Indonesia: Social and Cultural Revolution. Kuala Lumpur, Malaysia: Oxford University Press.

Altbach, P. and T. Umakoshi. 2004. Asian Universities: Historical Perspectives and Contemporary Challenges. Baltimore, MD: Johns Hopkins University Press.

Ananta, A. 2013. "Changing Ethnic Composition: Indonesia, 2000-2010." XXVII IUSSP International Population Conference, Busan, Korea.

Asari, H. 2007. "Islamic Higher Education in Indonesia." Analytica Islamica, No. 9 (1):1-16.

Asian Development Bank. 2012. Financing Higher Education in Asia and Pacific. Manila, Phillipines: Asian Development Bank.

Beerkens, E. 2002. "Moving towards Autonomy in Indonesian Higher Education." International Higher Education, No. 29 (Fall):24-25.

Buchori, M. and A. Malik. 2004. "The Evolution of Higher Education in Indonesia." In Asian Universities: Historical Perspectives and Contemporary Challenges, ed. P. Altbach and T. Umakoshi. Baltimore, MD: Johns Hopkins University Press. 249-277.

Clark, N. 2014. "Education in Indonesia." World Education News and Reviews, April 4, 2014.

Cummings, W. and S. Kasenda. 1989. "The Origin of Modern Indonesian Higher Education." In From Dependence to Autonomy: The Development of Asian Universities, ed. P. Altbach and V. Selvaratnam. Boston, MA: Kluwer Academic. 143-166.

Editor. "Time to Scrap the National Exams." JakartaGlobe. April 17, 2012.

Geoffroy, G., A. Goodman, D. Merrill and C. Morrison. 2009. Report of the U.S. Higher Education Leaders Mission to Indonesia: Recommendations on U.S.-Indonesia Enhanced Cooperation in Higher Education under the Planned "Comprehensive Partnership". Washington, DC: USINDO.

Global Business Guide Indonesia. 2013. Indonesia's Higher Education Act 2012. Available online at:

http://www.gbgindonesia.com/en/education/article/2012/indonesia_s_higher_education_a ct_2012.php.

Hartano, W. 2009. The 2010 Indonesia Population Census. Jakarta, Indonesia: Biro Pasat Statistik.

Hawkins, J. 2011. "Variations on Equity and Access in Higher Education in Asia." In Access, Equity, and Capacity in Asia-Pacific Higher Education, ed. D. Neubauer and Y. Tanaka. New York City, NY: Palgrave Macmillan. 22-44.

Indonesian Central Agency on Statistics. 2010. Population Census. Jakarta, Indonesia: Badan Pusat Statistik.

Irandoust, S. 2014. "High Time for Internationalization of Indonesian Higher Learning." Jakarta Post, January 11, 2014.

Jacob, J., Y. Wang, T. Pelkowski, R. Karsidi, and A. Priyanto. 2012. "Higher Education Reform in Indonesia: University Governance and Autonomy." In University Governance and Reform. Policy, Fads, and Experience in International Perspective, ed. H. Schuetze, W. Bruneau and G. Grosjean. New York, NY: Palgrave Macmillan. 225-239 
Koning, J., and E. Maassen. 2012. "Autonomous Institutions? Local Ownership in Higher Education in Eastern Indonesia." International Journal of Business Anthropology, No. 3 (2):54-74.

Kubo, A. 2013. "Indonesian Education Falls Behind Its Economic Growth." Diplomat, December 26, 2013.

Kusumadewi, L. and A. Cahyadi. 2013. "The Crisis of Public Universities in Indonesia Today." Universities in Crisis: Blog of the International Sociological Association (ISA). Available online at: http://www.isa-sociology.org/universities-in-crisis/?p=1010 .

Logli, C. 2015. Bhinneka Tunggal Ika (Unity in Diversity): Nationalism, Ethnicity, and Religion in Indonesian Higher Education (Ph.D. dissertation). University of Hawaii at Manoa.

Logli, C. in press-a. "Cultural Studies in Education: Filming Fluid Subjectivities in Indonesian Universities." Pedagogy, Culture and Society.

Logli, C. in press-b. "Higher Education and the Public Good: Creating Inclusive and Diverse National Universities in Indonesia in the Era of Globalization." In Redefining Asia Pacific Higher Education in a Global Context, ed. D. Neubauer and C. Collins. New York, NY: Palgrave Macmillan.

Mason, T., R. Arnove, and M. Sutton. 2001. "Credits, Curriculum, and Control in Higher Education: Cross-national Perspectives." Higher Education, No. 42 (1):107-137.

Mengglobal. "US Trends in Indonesian Student Enrollment." JakartaGlobe, March 28, 2013. Merrill, D. 2012. "US-Indonesia Relations: Re-engaging America's Universities." Strategic Review, No. 2 (1):19-25.

Moeliodihardjo, B., B. Soemardi, S. Brodjonegoro, and S. Hatakenaka. 2012. "University, Industry, and Government Partnership: Its Present and Future Challenges in Indonesia." Procedia-Social and Behavioral Sciences, No. 52:307-316.

Moeliodihardjo, B. 2014. Higher Education Sector in Indonesia. Jakarta, Indonesia: British Council.

Nizam. 2006. "Indonesia." In Higher Education in South-East Asia, ed. UNESCO. Bangkok, Thailand: UNESCO. 35-68.

NUFFIC. 2015. Education System Indonesia: The Indonesian Education System Described and Compared with the Dutch System. Hague, Netherlands: NUFFIC.

OECD/Asian Development Bank. 2015. Education in Indonesia: Rising to the Challenge. Paris, France: OECD.

Oey-Gardiner, M. and R. Suprapto. 1996. "Indonesia." In Women, Education, and Development in Asia: Cross-national Perspectives, ed. G. Mak. Levittown, PA: Garland Publishing. 95-118.

Pardoen, S. 1998. Assessment of Investment in Private Higher Education in Indonesia: The Case of Four Private Universities. Jakarta, Indonesia: Centre for Societal Development Studies, Atma Jaya Catholic University.

Pincus, J. 2015. "For Indonesian Higher Education, It's Time to Grow up." Nikkei Asian Review, April 27, 2015.

Rachman, A. 2015. "What's Different about this Year's National Exams in Indonesia?" Wall Street Journal, April 13, 2015.

Rais, A. 1987. "Muslim Society, Higher Education and Development: The Case of Indonesia." In Muslim Society, Higher Education and Development in Southeast Asia, ed. A. Sharom and S. Siddique. Singapore: Institute of Southeast Asian Studies. 9-27. 
Sihombing, E., T. Mattangkilang, and N. Setuningsih. "Probe of National Exam Delay Promised as Education Ministry Acknowledges 'Disaster'." Jakarta Globe. April 22, 2013.

Sitepu, I. 2013. Competencies of Higher Education Graduates: A Case of Universitas Kristen Indonesia (Ph.D. dissertation). Kassel University.

Soedijarto. 2009. "Some Notes on the Ideals and Goals of Indonesia's National Education System and the Inconsistency of its Implementation: A Comparative Analysis." Journal of Indonesian Social Sciences and Humanities, No. 2:1-11.

Soejatminah, S. 2009. "Internationalisation of Indonesian Higher Education: A Study from the Periphery." Asian Social Science, No. 5 (9):70-78.

Soekartawi, S., A. Haryono, and F. Librero. 2012. "Great Learning Opportunities through Distance Education: Experiences in Indonesia and the Philippines." Journal of Southeast Asian Education, No. 3 (2):283-320.

Sunarto, K. 2015. "Corporatizing Indonesian Higher Education." Global Dialogue, No. 5 (1). Available online at: http://isa-global-dialogue.net/corporatizing-indonesian-highereducation-2/.

Sunarto, K., R. Heng, and A. Saifuddin. 2004. Multicultural Education in Indonesia and Southeast Asia: Stepping into the Unfamiliar. Depok, Indonesia: Jurnal Antropologi Indonesia.

Susanti, D. 2011. "Privatisation and Marketisation of Higher Education in Indonesia: The Challenge for Equal Access and Academic Values." Higher Education, No. 61 (2):209218.

Tadjudin, M. K. 2009. "Quality Assurance in Indonesian Higher Education." In Higher Education in Asia/Pacific: Quality and the Public Good, ed. T. Bigalke and D. Neubauer. New York City, NY: Palgrave Macmillan. 147-164.

UNESCO. 2010. Institute for Statistics - Data Center. UNESCO. Available online at: http://stats.uis.unesco.org.

Welch, A. 2007. "Blurred Vision?: Public and Private Higher Education in Indonesia." Higher Education: The International Journal of Higher Education and Educational Planning, No. 54 (5):665-687.

Welch, A. 2011. Higher Education in Southeast Asia: Blurring Borders, Changing Balance. New York City, NY: Routledge.

Welch, A. 2012. "The Limits of Regionalism in Indonesian Higher Education." Asian Education and Development Studies, No. 1 (1):24-42.

Wicaksono, T. and D. Friawan. "Recent Developments in Higher Education in Indonesia: Issues and Challanges." In Financing Higher Education and Economic Development in East Asia, ed. S. Armstrong and B. Chapman. Canberra, Australia: Australinan National University. 159-187. 